\title{
Antibacterial and Antibiofilm Activities of Nigella sativa L. Seed Extracts
}

\author{
Md. Shafiqur Rahman* and Tithi Roy \\ Department of Microbiology, University of Chittagong, Chattogram-4331, Bangladesh.Email: mrahman7@lakeheadu.ca
}

\begin{abstract}
The emergence of antibiotic-resistant bacteria is a major public health problem. Consequently, the development of new antimicrobials that act on novel bacterial targets and are less susceptible to resistance are of primary importance to researchers in academia and industry alike. The present study was aimed to determine the antimicrobial and antibiofilm activities of Nigella sativa seed extracts. For this, primary (qualitative) and quantitative antibacterial activities of Nigella sativa seed extracts were determined against ten human pathogenic bacteria including four biofilm producing bacterial strains Escherichia coli, Pseudomonas aeruginosa, Klebsiella pneumoniae and Staphylococcus aureus. The antibacterial activities as well as minimum inhibitory concentration (MIC) and minimum bactericidal concentration (MBC) of the extracts were evaluated using disc diffusion and macro-broth dilution methods, respectively. The seed extracts of $N$. sativa exhibited the highest extract yields (w/v) $23.3 \%$ and $21.35 \%$ with ethanol and petroleum ether, respectively. The crude extract (essential oil) of petroleum ether exhibited superior antibacterial activity ( $36 \mathrm{~mm}$ in diameter zone of inhibition) against biofilm forming $E$. coli on a disc diffusion assay at a concentration of $1000 \mu \mathrm{g} / \mathrm{disc}$ when compared to that of ethanolic crude extract. Moreover, the lowest MIC and MBC values were determined as $500 \mu \mathrm{g} / \mathrm{ml}$ and $1500 \mu \mathrm{g} / \mathrm{ml}$ respectively with the same petroleum ether extract against $E$. coli. However, $N$. sativa essential oil obtained from petroleum ether extract of seed inhibited $94 \%$ biofilm formation of $E$. coli at $2 \times$ MIC concentration. Moreover, at the same concentration $(2 \times \mathrm{MIC})$, the ethanol extract inhibited $56 \%$ biofilm formation of $P$. aeruginosa. These results consistently revealed that it is possible to isolate novel antimicrobial agents capable of completely eradicating microbial infections including antibiotic resistance. Therefore, bioactive natural products present in plant resources would represent a noteworthy alternative to commercial antibiotics helping treatment of human antibiotic resistant infections.
\end{abstract}

Keywords: Antibacterial activity, Antibiofilm activity, Nigella sativa, Seed extract.

\section{Introduction}

Microorganisms have developed resistance to many antibiotics, and this has created immense clinical problems in the treatment of infectious diseases ${ }^{1}$. The biofilm mode of growth is the survival strategy of many environmental bacteria like Pseudomonas aeruginosa, Staphylococcus aureus, Klebsiella pneumoniae, Escherichia coli and Burkholderia cepacia ${ }^{2}$. Although the above biofilm producing bacterial species are generally not virulent in healthy persons, these opportunists can cause severe and chronic respiratory tract infections in individuals with cystic fibrosis $(\mathrm{CF})^{3}$. Unremitting infections and the associated inflammation result in progressive lung disease that culminates in pulmonary failure, the leading cause of death for CF patients. Effective therapy of CF pulmonary infection is severely limited by the broad-spectrum antimicrobial resistance exhibited by these species, which are among the most drug-resistant bacteria encountered in human infections. This situation forced scientists to search for new antimicrobial substances from various sources. These challenges have driven an increase in recent efforts to develop novel and efficient antimicrobial agents against these drug resistant pathogens.

Now-a-days, the natural products from plant extracts have been accepted as an important source of biologically active (antimicrobial) substances ${ }^{4-6}$ and the major sources of which are still left undiscovered. It has now been discovered that secondary metabolites of some plants have surprisingly useful therapeutic properties and many of them are found to be active against multidrug resistant pathogens ${ }^{7}$. The crude extracts from some dietary berries showed quorum sensing (QS) inhibitory activity against biofilm forming bacteria like $P$. aeruginosa. The effective phytochemicals inhibited the bacteria from recognizing a critical density of bacteria, i.e., quorum sensing (QS), and responding with the production of the biofilm-triggering chemical ${ }^{8}$. Even today, $85 \%$ of Indians use higher plants as effective antimicrobials for the treatment of various diseases ${ }^{8}$. A large number of antimicrobial agents derived from traditional medicinal plants are available for treating various diseases caused by microorganisms ${ }^{10-11}$. Since these antimicrobial agents are derived from plant resources, they are generally recognized as safe and are rarely associated with any side-effects as seen in many antibiotic regimens ${ }^{12}$.

Nigella sativa L., belonging to the family Ranunculaceae, is widely distributed in Eastern Europe, Middle East, and Western Asia $^{13}$. The plant is a bushy small shrub with tapering green leaves and white or pale to dark blue flowers. Its tiny black seeds mainly contain biologically active $35 \%$ fixed and essential oils ${ }^{14}$, also 
contain $21 \%$ proteins, $29 \%$ carbohydrates, $6 \%$ crude fibers, $5 \%$ moisture, and $4 \%$ ash $^{15}$. Therefore, three biological active compounds thymoquinone, carvacrol, and p-cymene have been reported in the essential oils of $N$. sativa seed, which have broad spectrum antimicrobial activity ${ }^{14,16}$. The seeds of the $N$. sativa locally known as Kalonji or Kalojera which has been used in traditional and alternative medicines for the treatment of asthma, diarrhea, parasitic diseases, and allergy ${ }^{17-19}$. The present study was aimed to determine the antimicrobial and antibiofilm activities of Nigella sativa seed extracts.

\section{Materials and methods}

\section{Seed extract for primary screening}

Dried seeds of $N$. sativa were collected from local market, washed thoroughly using distilled water, dried in oven at $50^{\circ} \mathrm{C}$ and powdered mechanically. The powdered sample was extracted using five different organic solvents ethanol, chloroform, ethyl acetate, carbon tetrachloride and Petroleum ether. However, for extraction of primary screening, the sample was steeped separately into $95 \%$ ethanol and petroleum ether at a ratio of $1: 3$ (plant material: organic solvent) for 48 hours. The solvent extracts were collected separately by filtration. These crude extracts were then tested for primary screening of antibacterial activity against ten human pathogenic bacteria by disc diffusion method ${ }^{19}$.

\section{Seed extract for quantitative antibacterial and antibiofilm} activities

A measured amount (200g) of dried powder of $N$. sativa seeds were kept in dried $500 \mathrm{ml}$ conical flask and steeped separately in $95 \%$ ethanol and petroleum ether at room temperature for five days. Each extract was then passed through the clean cheesecloth for removing plant materials and then filtered through Whatman filter paper No.-1. The filtrate was then concentrated under reduced pressure at $45-50^{\circ} \mathrm{C}$ using rotary vacuum evaporator, put into oven at $45^{\circ} \mathrm{C}$ until dry. The concentrated extract thus obtained is termed as dried crude extract. The dried crude extract obtained from petroleum ether extract was yellowish-pink essential oil. The crude extract was stored in sealed vials at $4^{\circ} \mathrm{C}$.

\section{Determination of extract yield}

The crude extract was weighed and the percentage yield of each was calculated as follows:

Extract yield $\%=\mathrm{W} 1 / \mathrm{W} 2 \times 100$

Here, $\mathrm{W} 1=$ Net weight of dried crude extract in grams after extraction.

And $\mathrm{W} 2=$ Total weight of plant sample powder in grams taken for extraction.

Test organisms

Escherichia coli ATCC25923, Pseudomonas aeruginosa ATCC8027, Salmonella abony NCTC6017, Klebsiella pneumoniae ATCC13883, Vibrio cholerae AE14748, Shigella dysenteriae AE14612, Acinetobacter baumannii ATCC17978,
Bacillus cereus BTCC19, Bacillus subtilis ATCC6633 and Staphylococcus aureus ATCC6538.

Crude extract solution for quantitative antibacterial and antibiofilm assay

A measured amount of dried crude extract or essential oil was dissolved in definite volumes of ethanol/DMSO to give solution $(10 \%)$ of known concentration. From this solution desired concentrations were used for further test.

\section{Treatment of paper disc by extracts}

Solutions of known concentration of the crude extract or essential oil were prepared by dissolving measured amount of the sample in definite volume of solvent. Dried and sterilized filter paper discs were treated with known concentration of extract using micropipette. However, extracts for primary screening, $4 \mathrm{~mm}$ in diameter paper discs were soaked with the respective extract.

\section{Antibacterial activity assay}

The antibacterial activities of the $N$. sativa seed extracts were done by disc diffusion method ${ }^{20}$ and Muller-Hinton agar (17.5 $\mathrm{g} / \mathrm{L}$ acid hydrolysate of casein, $2 \mathrm{~g} / \mathrm{L}$ beef extract, $1.5 \mathrm{~g} / \mathrm{L}$ starch and $15 \mathrm{~g} / \mathrm{L}$ agar) medium was used. However, for seed culture of test bacteria, Luria-Bertani (LB) broth $(10 \mathrm{~g} / \mathrm{L}$ peptone, $5 \mathrm{~g} / \mathrm{L}$ yeast extract and $10 \mathrm{~g} / \mathrm{L} \mathrm{NaCl}$ ) medium was used. For in vitro sensitivity of the bacteria to the test materials, paper discs of 4 $\mathrm{mm}$ in diameter and petri dish of 100 or $150 \mathrm{~mm}$ in diameter were used throughout the experiment. All experiments were repeated three times.

Determination of Minimum Inhibitory Concentration (MIC) and Minimum Bactericidal Concentration (MBC)

MIC and MBC of crude extracts or essential oils of $N$. sativa seed were determined by macro dilution broth technique ${ }^{21}$. LuriaBertaini (LB) broth medium was used for bacterial culture. All experiments were performed in triplicate and the results are expressed as mean values of three replicates.

\section{Anti-biofilm Activity}

The effect of $N$. sativa seed extracts on biofilm formation was evaluated as described by Sandasi et al. (2010) $)^{22}$ with slightly modification mentioned in Christensen et al. (1985) ${ }^{23}$. Briefly, the solutions of extract equivalent to $0.5 \times \mathrm{MIC}, 1.0 \times \mathrm{MIC}$ and $2.0 \times$ MIC were prepared. Each sample solution of $0.5 \mathrm{~mL}$ was distributed into individual test tubes. Equal volumes of methanol or water were added as negative controls while tetracycline $(0.00125 \mathrm{mg} / \mathrm{ml})$ was added as a positive control. Then, $0.5 \mathrm{~mL}$ of each diluted overnight culture matched to 0.5 McFarland turbidity standard was added to the test tube to yield a final volume of $1.0 \mathrm{~mL}$ in each test tube and sterile $1.0 \mathrm{~mL} \mathrm{LB}$ broth was also added as an additional nutrient, before plugging the tubes. The test tubes were then incubated for $48 \mathrm{~h}$ at $37^{\circ} \mathrm{C}$ to allow cell attachment. Biofilm formation was assessed using the modified crystal violet assay described by Djordjevic et al. $(2002)^{24}$. After subsequent incubation, the content of each tube was carefully 
removed with a pipette without disturbing the biofilm. Test tubes were washed five times with sterile distilled water to wash away any loosely attached bacterial cells. Then the test tubes were air dried and further oven dried at $60^{\circ} \mathrm{C}$ for few minutes. The cells in the biofilm were then stained with $1 \%$ crystal violet and incubated at room temperature for 15 minutes. The test tubes were then washed three times with sterile distilled water to remove the excess stain and $2 \mathrm{~mL}$ of $95 \%$ ethanol was added to the test tube to de-stain the tube. The de-staining solution from each test tube was then transferred to new test tube and absorbance was measured at $530 \mathrm{~nm}$. The mean absorbance was used for determining the percentage of inhibition of biomass formation for each concentration using the following equation:

Percentage of inhibition $=100-\left[\left\{\left(\mathrm{OD}_{530} \mathrm{~nm}\right.\right.\right.$ of experimental $) /$ $\left(\mathrm{OD}_{530} \mathrm{~nm}\right.$ of control $\left.\left.)\right\} \times 100\right]$

\section{Results and Discussion}

Bacteria have the genetic ability to transmit and acquire resistance to drugs which are consumed as therapeutic agents. Therefore, resistant bacteria represent a challenge in the treatments of various well-known infections and requires the new substances with antimicrobial properties. Consequently, a great deal of attraction has been paid to the antimicrobial effects of plant extracts which show significant activity.

\section{Yielding percentage of extract}

Yielding percentages of crude extracts obtained using different solvents ethanol and petroleum ether were 21.35 and 23.3 respectively.

\section{Primary screening for antibacterial activity}

For primary screening, the ethanol, chloroform, ethyl acetate, carbon tetrachloride and petroleum ether extracts were screened primarily for their antibacterial activities against ten human pathogenic bacteria including four biofilm producing bacterial strains $P$. aeruginosa, E. coli, $K$. pneumoniae and $S$. aureus. The results of the primary screening for antibacterial activities are presented in Table 1.

In this screening test, $4 \mathrm{~mm}$ in diameter paper discs were soaked with the crude extracts. From Table 1, it was appeared that both ethanol and petroleum ether extracts exhibited the largest zone of inhibitions ( $8-13 \mathrm{~mm}$ in diameter) against all the organisms. Among the pet ether and ethanol extracts of $N$. sativa seeds, the pet ether extract showed comparatively the better antibacterial activities compared to that of other extracts. The ethanol extract also showed moderate zone of inhibitions from 8 to $11 \mathrm{~mm}$ in diameter against all the bacterial pathogens tested herein (Table 1). The largest zone of inhibition $13 \mathrm{~mm}$ in diameter was exhibited by pet ether extract against $K$. pneumoniae and P. aeruginosa (Table 1). Therefore, the ethanol and petroleum ether extracts were selected for quantitative antibacterial and antibiofilm activities test. Similar antimicrobial activities of other plant extracts have been reported previously ${ }^{25-28}$.

\section{Quantitative antibacterial activity of $N$. sativa seed extracts}

After primary selection, the ethanol and petroleum ether extracts of $N$. sativa seed were tested for antibacterial activities against ten bacterial pathogens including biofilm producing $P$. aeruginosa, E. coli, K. pneumoniae and S. aureus. Therefore, antimicrobial activities of ethanol and petroleum ether extracts of $N$. sativa seeds are presented in Table 2. From Table 2, it was appeared that crude extracts of 500 and $1000 \mu \mathrm{g} / \mathrm{disc}$ exhibited good inhibitions against all the ten bacterial pathogens. Moreover, $1000 \mu \mathrm{g} /$ disc extract exhibited the better inhibitions compared to that of $500 \mu \mathrm{g} / \mathrm{disc}$ concentration. The largest zone of inhibitions $28 \mathrm{~mm}$ and $19 \mathrm{~mm}$ in diameters were exhibited by 1000 and $500 \mu \mathrm{g} /$ disc methanol extracts, respectively against a biofilm producing bacterial pathogen $E$. coli (Table 2).

Table 1: Antibacterial activity of crude extracts of Nigella sativa seeds.

\begin{tabular}{|c|c|c|c|c|c|}
\hline \multirow[t]{2}{*}{ Test organisms } & \multicolumn{5}{|c|}{ Zone of inhibition ( $\mathrm{mm}$ in diameter) } \\
\hline & Ethanol & Ethyl acetate & Petroleum ether & Carbon tetrachloride & Chloroform \\
\hline Escherichia coli & 10 & 08 & 11 & 08 & 08 \\
\hline Klebsiella pneumoniae & 08 & 10 & 13 & 07 & 07 \\
\hline Staphylococcus aureus & 08 & 08 & 12 & 07 & - \\
\hline Salmonella abony & 09 & 07 & 08 & - & - \\
\hline Acinetbacter baumannii & 11 & 07 & 10 & 08 & 09 \\
\hline Bacillus cereus & 08 & - & 08 & 07 & 06 \\
\hline Bacillus subtilis & 10 & 10 & 11 & 06 & 08 \\
\hline Pseudomonas aeruginosa & 08 & 08 & 13 & 06 & 07 \\
\hline Vibrio cholerae & 09 & 08 & 11 & 09 & 06 \\
\hline Shigella dysenteriae & 08 & 07 & 10 & 07 & - \\
\hline
\end{tabular}

Note: Bold indicates the largest zone of inhibition. 
However, $1000 \mu \mathrm{g} / \mathrm{disc}$ petroleum ether extract (crude) of $N$. sativa seeds also showed the largest zone of inhibition $36 \mathrm{~mm}$ in diameter against E. coli (Table 2). Furthermore, the largest 25 $\mathrm{mm}$ in diameter zone of inhibition was obtained against biofilm producing bacterial pathogens $E$. coli and P. aeruginosa with $500 \mu \mathrm{g} /$ disc crude extract of petroleum ether. Thus, the crude extract of pet ether exhibited comparatively the better antibacterial activities that of ethanol extract (Table 2). Similar antimicrobial activity of other plant extracts as reported previously ${ }^{25-26,29}$. Hanafy and Hatem $(1991)^{30}$ showed the maximum zone of inhibition $(16 \mathrm{~mm})$ at $400 \mu \mathrm{g} / \mathrm{disc}$ of diethyl ether extract of $N$. sativa seeds against $S$. aureus.

Our results are in concurrence with the results reported previously by Chowdhury et al. $(2007)^{31}$. They found highest zone of inhibition $44 \mathrm{~mm}$ in diameter at $1000 \mu \mathrm{g} /$ disc and $27.5 \mathrm{~mm}$ in diameter at $500 \mu \mathrm{g} / \mathrm{disc}$ with the crude extract of Mikania cordata against Vibrio cholerae and Salmonella paratyphii, respectively. However, in this study, petroleum ether extract of $N$. sativa displayed $36 \mathrm{~mm}$ in diameter zone of inhibition against $E$. coli at $1000 \mu \mathrm{g} /$ disc concentration. Furthermore, Pattanayak et al. $(2015)^{32}$ evaluated the antimicrobial activity of succulent and methanol extracts of Mikania scandens. They found that the methanolic extract showed better effects against S. aureus. Soma et al. (2018) ${ }^{28}$ showed that ethanol extract had better antimicrobial activity than aqueous extract. However, the petroleum ether extract showed the better antibacterial activities than other extracts due to higher concentration of essential oils extracted from the Nigella sativa seeds.

Minimum inhibitory concentration (MIC) and minimum bactericidal concentration (MBC) of Nigella sativa seed extracts

MIC and MBC values of the crude extracts were determined by macro-dilution broth technique ${ }^{21}$. MIC and MBC provide information whether antimicrobial agents are either bacteriostatic or bactericidal.

MIC and MBC values of the ethanol and pet ether extracts of $N$. sativa seeds are shown in Table $3 \mathrm{~A}$ and Table $3 \mathrm{~B}$, respectively. The ethanol extract exhibited a wide range of MIC values from $1000 \mu \mathrm{g} / \mathrm{ml}$ to $2000 \mu \mathrm{g} / \mathrm{ml}$ against the bacterial pathogens tested herein (Table 3A). Similarly, the same ethanol extract demonstrated the $\mathrm{MBC}$ values ranging from $2500 \mu \mathrm{g} / \mathrm{ml}$ to $4000 \mu \mathrm{g} / \mathrm{ml}$ against the bacterial pathogens. The lowest MIC value $(1000 \mu \mathrm{g} / \mathrm{ml})$ was recorded against $E$. coli, and $P$. aeruginos $a$ with ethanolic extract of $N$. sativa seeds. On the other hand, the lowest MBC value (2500 $\mu \mathrm{g} / \mathrm{ml}$ ) was obtained against biofilm producing $P$. aeruginosa using the same ethanol extract (Table 3A).

Table 2: Quantitative antibacterial activities of ethanol and petroleum ether extracts of Nigella sativa seeds

\begin{tabular}{|c|c|c|c|c|}
\hline \multirow[t]{3}{*}{ Test organisms } & \multicolumn{4}{|c|}{ Zone of inhibition ( $\mathrm{mm}$ in diameter) } \\
\hline & \multicolumn{2}{|c|}{ Ethanol extract } & \multicolumn{2}{|c|}{ Petroleum ether extract } \\
\hline & $1000 \mu \mathrm{g} /$ disc & $500 \mu \mathrm{g} / \mathrm{disc}$ & $1000 \mu \mathrm{g} / \mathrm{disc}$ & $500 \mu \mathrm{g} / \mathrm{disc}$ \\
\hline Klebsiella pneumoniae & 25 & 16 & 32 & 22 \\
\hline Staphylococcus aureus & 17 & 13 & 26 & 17 \\
\hline Salmonella abony & 20 & 14 & 17 & 12 \\
\hline Bacillus cereus & 18 & 12 & 18 & 11 \\
\hline Bacillus subtilis & 16 & 11 & 17 & 11 \\
\hline Pseudomonas aeruginosa & 20 & 13 & 35 & 25 \\
\hline Vibrio cholerae & 19 & 11 & 21 & 14 \\
\hline Shigella dysenteriae & 18 & 12 & 22 & 13 \\
\hline
\end{tabular}

Note: Bolds indicate largest zone of inhibitions.

Table 3A: MIC and MBC of ethanol extract of Nigella sativa seeds against human pathogenic bacteria

\begin{tabular}{|c|c|c|c|c|c|c|c|}
\hline \multirow[t]{2}{*}{ Name of bacteria } & \multicolumn{5}{|c|}{$\begin{array}{l}\text { Bacterial growth in LB broth } \\
\text { (Extract concentration } \mu \mathrm{g} / \mathrm{ml} \text { ) }\end{array}$} & \multirow[t]{2}{*}{$\mathrm{MIC} \mu \mathrm{g} / \mathrm{ml}$} & \multirow[t]{2}{*}{$\mathrm{MBC} \mu \mathrm{g} / \mathrm{ml}$} \\
\hline & 500 & 1000 & 1500 & 2000 & 2500 & & \\
\hline Klebsiella pneumoniae & + & + & - & - & - & 1000 & 3500 \\
\hline Staphylococcus aureus & + & + & - & - & - & 1500 & 3500 \\
\hline Salmonella abony & + & + & + & - & - & 2000 & 3500 \\
\hline Bacillus cereus & + & + & + & - & - & 2000 & 4000 \\
\hline Bacillus subtilis & + & + & - & - & - & 1500 & 3500 \\
\hline Pseudomonas aeruginosa & + & - & - & - & - & 1000 & 2500 \\
\hline Vibrio cholerae & + & + & - & - & - & 1500 & 3500 \\
\hline Shigella dysenteriae & + & + & - & - & - & 1500 & 3500 \\
\hline
\end{tabular}

Note: $(+)$ indicates presence of growth and (-) means absence of growth. 
Table 3B: MIC and MBC of petroleum ether extract of Nigella sativa seeds against human pathogenic bacteria

\begin{tabular}{|c|c|c|c|c|c|c|c|}
\hline \multirow[t]{2}{*}{ Name of bacteria } & \multicolumn{5}{|c|}{$\begin{array}{l}\text { Bacterial growth in LB broth } \\
\text { (Extract concentration } \mu \mathrm{g} / \mathrm{ml} \text { ) }\end{array}$} & \multirow[t]{2}{*}{$\mathrm{MIC} \mu \mathrm{g} / \mathrm{ml}$} & \multirow[t]{2}{*}{$\mathrm{MBC} \mu \mathrm{g} / \mathrm{ml}$} \\
\hline & 250 & 500 & 1000 & 1500 & 2000 & & \\
\hline Escherichia coli & + & - & - & - & - & 500 & 1500 \\
\hline Klebsiella pneumoniae & + & - & - & - & - & 500 & 2000 \\
\hline Staphylococcus aureus & + & + & - & - & - & 1000 & 2500 \\
\hline Salmonella abony & + & + & + & + & - & 2000 & 3500 \\
\hline Acinetobacter baumannii & + & + & + & - & - & 1500 & 3500 \\
\hline Bacillus cereus & + & + & + & - & - & 1500 & 4000 \\
\hline Bacillus subtilis & + & + & + & - & - & 1500 & 3500 \\
\hline Pseudomonas aeruginosa & + & + & - & - & - & 1000 & 2500 \\
\hline Vibrio cholerae & + & + & + & - & - & 1500 & 3500 \\
\hline Shigella dysenteriae & + & + & - & - & - & 1000 & 3000 \\
\hline
\end{tabular}

Note: $(+)$ indicates presence of growth and (-) means absence of growth.

The MIC and $\mathrm{MBC}$ values of pet ether extract were presented in Table 3B. In case of pet ether extract, the MIC values were 500 $\mu \mathrm{g} / \mathrm{ml}, 500 \mu \mathrm{g} / \mathrm{ml}, 1000 \mu \mathrm{g} / \mathrm{ml}, 2000 \mu \mathrm{g} / \mathrm{ml}, 1500 \mu \mathrm{g} / \mathrm{ml}, 1500$ $\mu \mathrm{g} / \mathrm{ml}, 1500 \mu \mathrm{g} / \mathrm{ml}, 1000 \mu \mathrm{g} / \mathrm{ml}, 1500 \mu \mathrm{g} / \mathrm{ml}$ and $1000 \mu \mathrm{g} / \mathrm{ml}$ against E. coli, K. pneumoniae, S. aureus, S. abony, A. baumannii, B. cereus, B. subtilis, P. auginosa, V. cholerae and S. dysenteriae, respectively (Table 3B). Moreover, the MBC values of the same pet ether extract were $1500 \mu \mathrm{g} / \mathrm{ml}, 2000 \mu \mathrm{g} / \mathrm{ml}, 2500 \mu \mathrm{g} / \mathrm{ml}, 3500$ $\mu \mathrm{g} / \mathrm{ml}, 3500 \mu \mathrm{g} / \mathrm{ml}, 4000 \mu \mathrm{g} / \mathrm{ml}, 3500 \mu \mathrm{g} / \mathrm{ml}, 2500 \mu \mathrm{g} / \mathrm{ml}, 3500$ $\mu \mathrm{g} / \mathrm{ml}$ and $3000 \mu \mathrm{g} / \mathrm{ml}$ against E. coli, K. pneumoniae, S. aureus, $S$. abony, A. baumannii, B. cereus, B. subtilis, $P$. aeruginosa, $V$. cholerae and $S$. dysenteriae respectively. The pet ether extract exhibited the lowest MIC value $500 \mu \mathrm{g} / \mathrm{ml}$ against $E$. coli, and $K$. pneumoniae. Moreover, the lowest MBC $1500 \mu \mathrm{g} / \mathrm{ml}$ was obtained against $E$. coli using pet ether extract of $N$. sativa seed extract (Table 3B). Similar MIC and MBC of the other plant extracts have been reported previously by many workers ${ }^{28,33-34}$.

From the above results, it was found that the petroleum ether of $N$. sativa seed extract exhibited good antibacterial activity against the organisms tested herein. Therefore, the extract could be used as a potential antibacterial agent against selected pathogenic bacteria.

\section{Anti-biofilm Activity}

The antibiofilm activities of these ethanol and petroleum ether extracts of Nigella sativa seeds against four biofilm forming pathogens E. coli, K. pneumoniae, P. aeruginosa and S. aureus were studied. Results of antibiofilm activities of ethanol and pet ether extracts are given in Figure 1 and Figure 2, respectively.

Ethanol extract of $N$. sativa seeds at a concentration of half of MIC $(0.5 \times$ MIC $)$ inhibited $27-30 \%$ biofilm formation, however, at MIC concentration it inhibited $35-49 \%$ biofilm formation of the four-biofilm forming bacterial pathogens tested herein (Fig. 1). Moreover, the same ethanol extract exhibited $48-56 \%$ biofilm inhibition at a concentration of double MIC $(2 \times \mathrm{MIC})$ against the same four biofilm producing bacterial strains. In case of double concentration of $\mathrm{MIC}(2 \times \mathrm{MIC})$, the ethanol extract exhibited the highest $56 \%$ and the lowest $48 \%$ of biofilm inhibitions against $P$. aeruginosa and $S$. aureus respectively (Fig. 1). However, at the MIC concentration of ethanol extract, the highest inhibition $49 \%$ of biofilm was documented with the bacterial pathogen $P$. aeruginosa. In case of $0.5 \mathrm{MIC}$ concentration, the ethanol extract exhibited the highest $30 \%$ and lowest $28 \%$ inhibitions of biofilms against $E$. coli and $S$. aureus, respectively (Fig. 1).

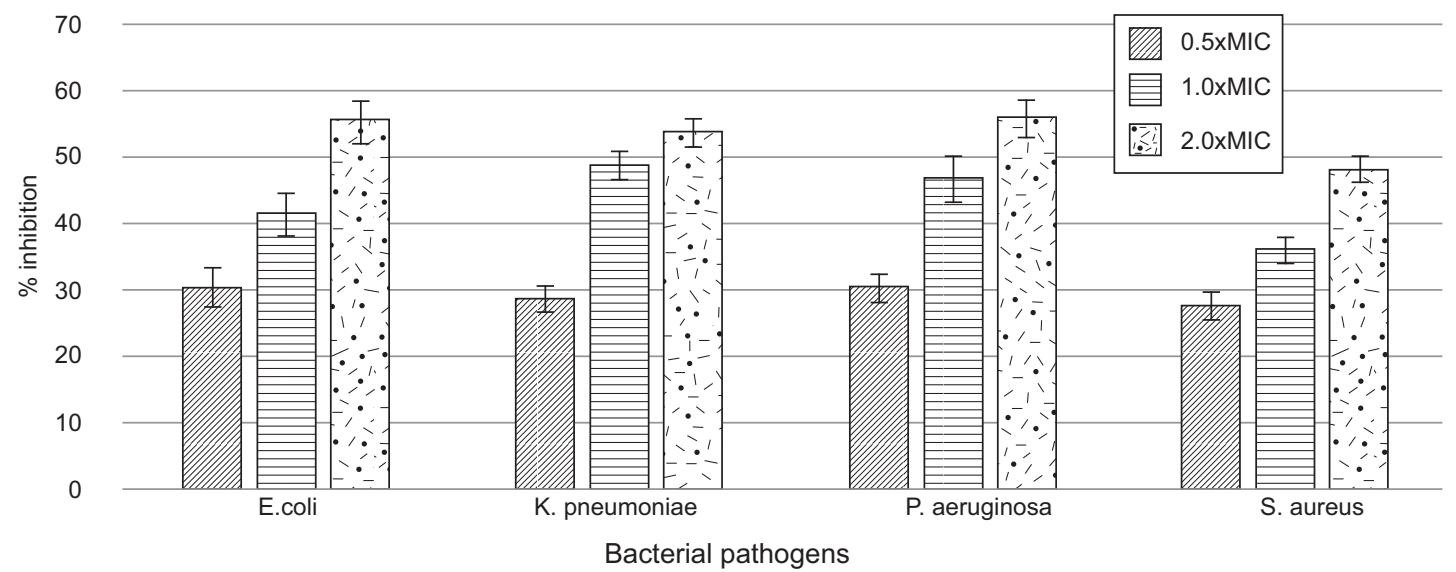

Fig. 1. Antibiofilm activity of ethanol extract of Nigella sativa seeds extract against E. coli, K. pneumoniae, P. aeruginosa and S. aureus. 
Rahman \& Roy

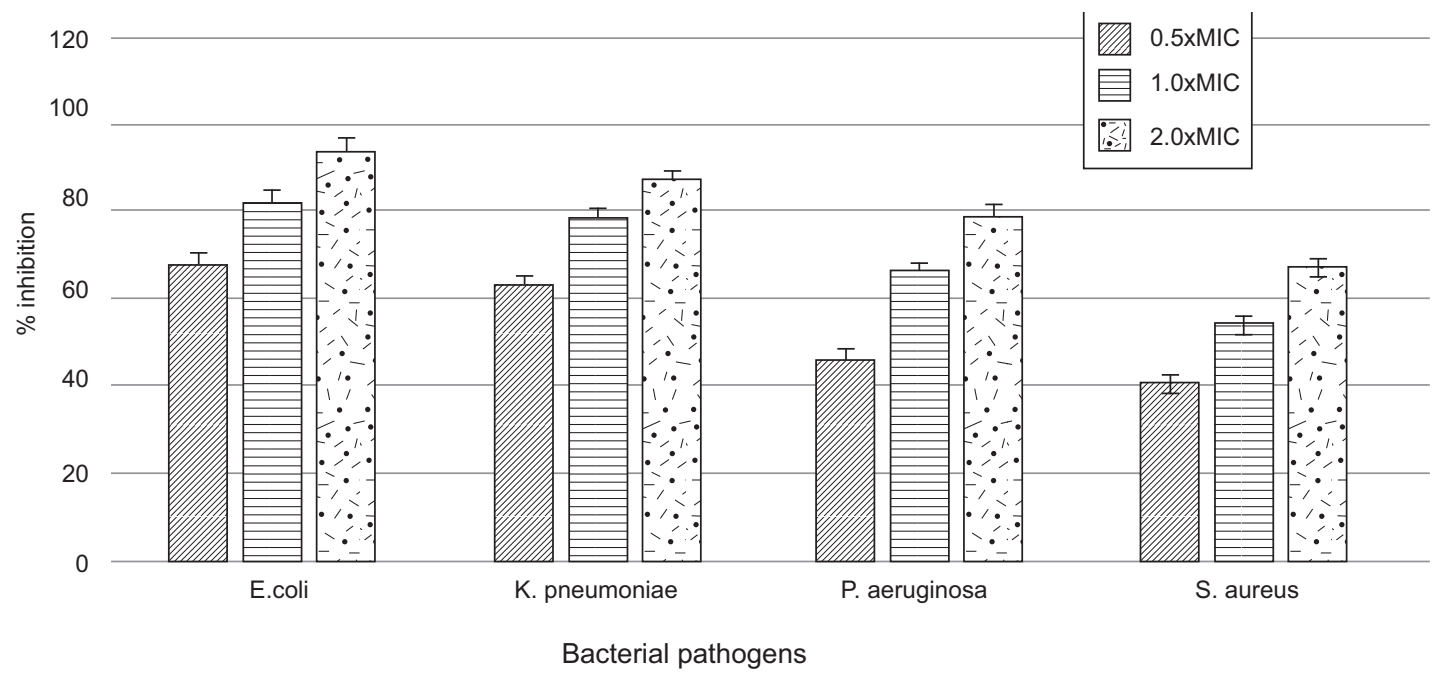

Fig. 2. Antibiofilm activity of petroleum ether extract of N. sativa seeds against E. coli, K. pneumoniae, P. aeruginosa and S. aureus.

The antibiofilm activities of petroleum ether extract (essential oil) of $N$. sativa seed against $E$. coli, $K$. pneumoniae, $P$. aeruginosa and $S$. aureus are presented in Figure 2. The crude extract (essential oil) obtained from petroleum ether extract of $N$. sativa seeds at half of MIC $(0.5 \times \mathrm{MIC})$ concentration inhibited $40-67 \%$ biofilm formation of four biofilm forming bacterial strains, and the highest inhibition $67 \%$ was recorded against $E$. coli (Fig. 2). However, the MIC concentration of the essential oil inhibited $54-82 \%$ biofilm formation of the four-biofilm forming bacterial pathogens, and the highest $82 \%$ inhibition was noted against the same bacterial strain E. coli. Also, the same essential oil exhibited $67-94 \%$ inhibition of biofilm production at a concentration of double MIC $(2 \times$ MIC $)$ against the same four biofilm producing bacterial strains. Moreover, for double concentration of $\mathrm{MIC}(2 \times \mathrm{MIC})$, the essential oil (petroleum ether extract) exhibited the highest $94 \%$ and the lowest $67 \%$ of biofilm inhibitions against $E$. coli and $S$. aureus, respectively (Fig. 2). The essential oil extracted from petroleum ether extract of $N$. sativa seeds exhibited comparatively the better inhibition of $E$. coli biofilm formation compared to that of other bacterial strains (Fig. 2). Similar antibiofilm activities of other plants extracts were also done by other workers ${ }^{35-36}$.

\section{Conclusion}

The use of herbal drugs as complementary medicine is prevalent and gaining worldwide popularity. It is evident from this study that ethanol and petroleum ether extracts obtained from Nigella sativa seeds exhibited good antibacterial activity against a wide range of bacterial pathogens. Consequently, these research findings so far have confirmed the antibiofilm potentials of Nigella sativa seeds against biofilm producing bacterial pathogens E. coli, K. pneumoniae, P. aeruginosa and S. aureus. These results consistently revealed that it is possible to isolate novel antibacterial agents capable of eradicating antibiotic resistant biofilm producing bacterial pathogens from plant resources. Thus, the research work could bring about a novel therapeutic agent from plant extracts that can overcome the antibiotic resistance problems and prevent biofilm formation of antibiotic resistant pathogens. Further investigations are required to isolate and characterize the pure compound(s) from Nigella sativa seed extracts which can then be tested for antimicrobial activity against antibiotic resistance as well as biofilm producing bacterial pathogens. The potent antibacterial agent of Nigella sativa seeds can be investigated further for in vivo studies including the mechanism of actions and its constituents by which they exert their therapeutic effects. Therefore, Nigella sativa seeds could be used as a potential antibacterial agent for the treatment of bacterial agents including biofilm producing strains.

\section{Acknowledgement}

This project work was supported by the grant of Planning and Development Office, University of Chittagong, Bangladesh.

\section{References}

1. Davis J. 1994. Inactivation of antibiotics and the dissemination of resistance genes. Science. 264: 375-382.

2. Donlan RM and Costerton JW. 2002. Biofilms: survival mechanisms of clinically relevant microorganisms. Clin Microbiol Rev. 15(2):167-193.

3. Brown SP, Cornforth DM and Mideo N. 2012. Evolution of virulence in opportunistic pathogens: generalism, plasticity, and control. Trends Microbiol. 20(7):336-342.

4. Jansen AM, Cheffer JJC and Svendsen AB. 1987. Antimicrobial activity of essential oils: A 1976-1986 literature review. Aspects of test methods. Planta Med. 40, 395-398.

5. Rahman MS, Yousuf M, Chowdhury JU, Begum J and Anwar MN. 2007. Antibacterial activity of 1,2-benzenedicarboxylic acid isolated from the root of Plumbago zeylanica L. Hamdard medicus. 50(3): 23-28.

6. Sultana R, Rahman MS, Bhuiyan MNI, Begum J and Anwar MN. 2008. In vitro antibacterial and antifungal activity of Borreria articularis. Bangladesh J Microbiol. 25(2): 95-98.

7. Nascimento GGF, Locatelli J, Freitas PC and Silva GL. 2000. Antibacterial activity of plant extracts and phytochemicals on antibiotic resistant. Brazilian J. Microbiol. 31:247-256.

8. Vattem DA, Mihalik K, Crixell SH and McLean RJC. 2007. Dietary phytochemicals as quorum sensing inhibitors. Fitoterapia. 78: 302-310.

9. Kamboj VP. 2000. Herbal medicine. Curr Sci. 78: 35-39. 
10. Jain, S. K. 1994. Ethnobotany and research on medicinal plants in India. Ciba Found Symp. 185:153-64.

11. Rahman MS and Anwar MN. 2008. Antibacterial and cytotoxic activity of longiverbenone isolated from the rhizome of Cyperus scariosus. Bangladesh J. Microbiol. 25(1): 82-84.

12. Vattem DA. and Shetty K. 2005. Functional phytochemicals from cranberries: their mechanism of action and strategies to improve functionality. In: Shetty KT, Pometto A and Levin RE edited. Food biotechnology. 2nd ed. New York: Marcel Dekker Inc. p. 789.

13. Zohary D, Hopf M and Weiss E. 2012. Domestication of Plants in the Old World: The Origin and Spread of Domesticated Plants in Southwest Asia, Europe, and the Mediterranean Basin. Oxford University Press on Demand.

14. Ahmad A, Husain A, Mujeeb M, Khan SA, Najmi AK. Siddique NA, Damanhouri ZA. and Anwar F. 2013. A review on therapeutic potential of Nigella sativa: a miracle herb. Asian Pacific J Tropical Biomedicine. 3(5):337-352.

15. Nergiz C and Ötle S. 1993. Chemical composition of Nigella sativa L. seeds. Food Chem. 48: 259-261.

16. Jrah HH, Kouidhi B, Flamini G, Bakhrouf A and Mahjoub T. 2011. Chemical composition, antimicrobial potential against cariogenic bacteria and cytotoxic activity of Tunisian Nigella sativa essential oil and thymoquinone. Food Chem. 129(4):1469-1474.

17. Gilani AH, Aziz N, Khurram IM, Chaudhary KS and Iqbal A. 2001. Bronchodilator, spasmolytic and calcium antagonist activities of Nigella sativa seeds (Kalonji): A traditional herbal product with multiple medicinal uses. J Pakistan Med Association. 1(3):115-120.

18. Abdulelah HAA and Zainal-Abidin B. 2007. In vivo anti-malarial tests of Nigella sativa (Black Seed) different extracts. American J Pharmacol and Toxicology. 2(2):46-50.

19. Benhaddou-Andaloussi,A, Martineau L, Vuong T, Meddah B, Madiraju P, Settaf A and Haddad PS. 2011. The in vivo antidiabetic activity of Nigella sativa is mediated through activation of the AMPK pathway and increased muscle Glut 4 content. Evid Based Complement and Alternat Med. doi: $10.1155 / 2011 / 538671$

20. Bauer AW, Kirby MM, Sherris JC and Truck M. 1996. Antibiotic susceptibility testing by a standardized single disc method. Amer J Clin Path. 45:493-496.

21. Jones NR, Barry LA, Gavan LT and Washington JA. 1985. Manual of Clinical Microbiology. $4^{\text {th }}$ ed. American Society for Microbiology, Washington D. C., pp. 972-976.

22. Sandasi M., Leonard CM and Viljoen AM. 2010. The in-vitro antibiofilm activity of selected culinary herbs and medicinal plants against Listeria monocytogenes. Letter Applied Microbiol. 50(1): 30- 35.
23. Christensen GD, Simpson WA, Bisno AL and Beachey EH. 1985. Adherence of coagulase-negative Staphylococci to plastic tissue culture plates. J Clinical Microbiol. 22: 996-1006.

24. Djordjevic D, Wiedmann M and McLandborough LA. 2002. Microtiter plate assay for assessment of Listeria monocytogens biofilm formation. Appl Env Microbiol. 68: 2950-2958.

25. Raman MS, Anwar MN and Chowdhury AZMS. 1999. Antibacterial activity of Secondary metabolites from Holarrhena antidysenterica stem bark. Bangladesh J Microbiol. 16(2): 101-105.

26. Rahman MS, Muhsin MDA and Anwar MN. 2001. Antimicrobial activity of crude alkaloids of Holarrhena antidysenterica root bark. Bangladesh $J$ Life Sci. 13(1\&2):193-6.

27. Rahman MS and Anwar MN. 2007. Antimicrobial activity of crude extract obtained from root of Plumbago zeylanica. Bangladesh J Microbiol. 24(1): 73-75.

28. Soma I, Manjunath YS and Mohan GV. 2018. Antidiarrheal and antimicrobial activities of Ethnomedicinal plant: Mikania scandens (L.) Willd. Sch Acad J Pharm. 7(3): 139-147.

29. Kumar Y, Agarwal S, Srivastava A, Kumar S, Agarwal G and Khan MZA. 2014. Antibacterial activity of Clove (Syzygium aromaticum) and Garlic (Allium sativum) on different pathogenic bacteria. Int J Pure App Bio Sci. 2(3): 305-311.

30. Hanafy MS and Hatem ME. 1991. Studies on the antimicrobial activity of Nigella sativa seed (black cumin). J Ethnopharmacol. 34(2-3):275178 .

31. Chowdhury JU, Yusuf M, Begum J, Sultana SA and Anwar MN. 2007. Antimicrobial activity of Mikania cordata. The Chittagong Univ J Bio Sci. 2(1\&2): 09-16.

32. Pattanayak S, Das P, Mandal TK, Debnath PK and Bandyopadhyay SK. 2015. A study on comparative antimicrobial and wound healing efficacy of solvent extracts and succulent leaf extract of Mikania scandens (L.) Willd. Amer J Phytomed and Clin Therapeutics. 3(4): 346-362.

33. Rahman MS, Sultana N and Anwar MN. 2004. In vitro antimicrobial activity of halarrifine-24ol isolated from the stem bark of Holarrhena antidysenterica. International J Agri. and Biol. 6 (4): 698-700.

34. Li Y, Li J, Li Y, Wang X-x and Cao A-c. 2013. Antimicrobial Constituents of the Leaves of Mikania micrantha. PLoS ONE. 8(10): 76-725.

35. Palombo A, Jadhav S, Shah R, Bhave M and Enzo P. 2013. Inhibitory activity of yarrow essential oil on Listeria planktonic cells and biofilms. Food Control. 29: 125-130.

36. Zhang Yi, Wang Y., Xiaojing ZP, Cao SW and Yanhua Lu. 2017. Antibacterial and antibiofilm activities of eugenol from essential oil of Syzygium aromarticum (L.) leaf against periodontal pathogens Porphyromonas gingivalis. Microb Pathol. 113: 396-402. 